\section{DIGITAL COMMONS \\ @ UNIVERSITY OF SOUTH FLORIDA}

\section{Suburban Sustainability}

\title{
Preserving the Historic Garden Suburb: Case Studies from London and New York
}

Jeffrey A. Kroessler

John Jay College of Criminal Justice, CUNY, jkroessler@jjay.cuny.edu

Follow this and additional works at: https://digitalcommons.usf.edu/subsust

Part of the Architectural History and Criticism Commons, Historic Preservation and Conservation Commons, and the Urban, Community and Regional Planning Commons

\section{Recommended Citation}

Kroessler, Jeffrey A. (2014) "Preserving the Historic Garden Suburb: Case Studies from London and New York," Suburban Sustainability. Vol. 2 : Iss. 1 , Article 1.

http://dx.doi.org/10.5038/2164-0866.2.1.1

Available at: https://digitalcommons.usf.edu/subsust/vol2/iss1/1

This Article is brought to you for free and open access by the Open Access Journals at Digital Commons @ University of South Florida. It has been accepted for inclusion in Suburban Sustainability by an authorized editor of Digital Commons @ University of South Florida. For more information, please contact digitalcommons@usf.edu. 


\section{Introduction}

In all the discussions of sustainability, historic preservation rarely makes an appearance. Energy efficiency, recycled materials, green roofs, LEED certification, solar power and windmills, even bike racks - all are popularized as acceptable elements of sustainable architecture. Economic justice, environmentalism, and social justice are the primary concerns of sustainability advocates. Environmental planning addresses the preservation of open space and greenbelts, but rarely the preservation of the built environment (Young 2002). Restoring or maintaining historic buildings is generally not counted as green by environmental advocates. But really, the greenest building is the one that is already built. Whether in terms of the natural materials utilized - stone, terra cotta, brick, wood, plaster - or embodied energy - the labor and resources that went into producing the structure - or simply not contributing to the waste stream - construction debris is perhaps the largest single contributor to landfills - historic buildings are inherently sustainable. Considering the entire life cycle of a structure, "older buildings compare quite favorably to new construction" (Allison and Peters 2011). But they do age, and the needs, tastes, and values of the society which must maintain them are surely different from those of the society that built them.

In the early years of the twentieth century, a new urban form emerged in England, the garden city, or garden suburb. That idea crossed the Atlantic almost immediately, not surprisingly as New York shared many of the housing ills that plagued London. Yes, the planned garden suburb emerged out of a utopian impulse, a vision of what urban living could be if we were only bold enough to start anew, but it was also a pragmatic response to the overcrowded, unsanitary, unhealthy, and socially destructive conditions found in European and American cities. (Fishman 2002) In the first three decades of the twentieth century, three planned communities were built just north of London: Letchworth Garden City, Hampstead Garden Suburb, and Welwyn Garden City. In the 1910s and 1920s, three garden suburbs were built in the Borough of Queens in New York City: Forest Hills Gardens, Jackson Heights, and Sunnyside Gardens.

Once the garden suburb was the future of urban living. Lewis Mumford called them "harbingers of a new age" (Mumford 1965). Those historic planned communities are now a century old, but while they surely belong to the past, they are certainly neither obsolete nor irrelevant. But even the best built homes can deteriorate over time, and we must ask how best to restore them, or whether it would be better to replace the entire structure and build something reflecting contemporary needs. The question, then, is whether the "Garden Cities of To-Morrow" are sustainable today.

Ebenezer Howard launched the movement in 1898 with Tomorrow: a Peaceful Path to Real Reform (republished in 1902 as Garden Cities of To-Morrow), wherein he posited that a new kind of residential development in the country could be both economically and socially viable and at the same time would alleviate the ills associated with growing cities (Howard 1965). In Mumford's view, Howard "laid the foundation for a new cycle of urban civilization: one in which the means of life will be subservient to the purposes of living, and in which the pattern needed for biological survival and economic efficiency will likewise lead to social and personal fulfillment" (Mumford 1965). If the cities of the late nineteenth century, characterized by poisonous air and unhealthy and overcrowded living conditions, deadened human potential, the garden suburb would release it and nurture healthy, creative, and humanistic lives.

Our purposes in building suburban housing may have become less utopian in the century since, but the garden suburbs around London and New York endure in their original form, 
remarkable in itself, and remain highly desirable among homebuyers, despite, or more often because of, the controls and regulations imposed upon residents. "How lucky we are to live here," exclaims the cover of a membership brochure for the Hampstead Garden Suburb Residents Association. Inside the text continues: "It's not just luck. The Suburb has been kept the way it is as a result of the concern and involvement of the people who have lived here since the beginning" (Hampstead Garden Suburb Residents Association, n.d).

The survival of these historic planned communities is not accidental. Each has been highly regulated from its inception, with limitations upon new construction and alterations to existing homes extending even to plantings and paint trim. These places are well known among urban historians and historians of planning, but their focus is on the original design and construction, the historical context for their creation, and the social, economic and cultural ideas of the planners. Stanley Buder's Visionaries and Planners typifies that approach (Buder 1990). Rarely is the story carried forward through the tedium of maintenance, regulation, lawsuits, and demographic change. Discussing Radburn, New Jersey, in Historic Preservation and the Livable City, Eric Allison and Lauren Peters describe the key components of that 1920s automobile suburb, but do not ask how the community was sustained over the decades, nor do they analyze the mechanisms in place to enforce aesthetic standards (Allison and Peters 2011).

\section{The First Garden Suburbs}

\section{Letchworth Garden City}

Unlike other idealists, Ebenezer Howard endeavored to put his ideas into practice and in 1903 formed a private company, First Garden City Ltd., to bring his vision to fruition. The result was the world's first garden city, Letchworth Garden City (Figure 1). Howard's company retained control over all buildings and landscaping until 1962, when by an act of Parliament all assets, rights, and responsibilities were transferred to a new public entity, the Letchworth Garden City Corporation. (Miller 1989) In 1995, another act of Parliament

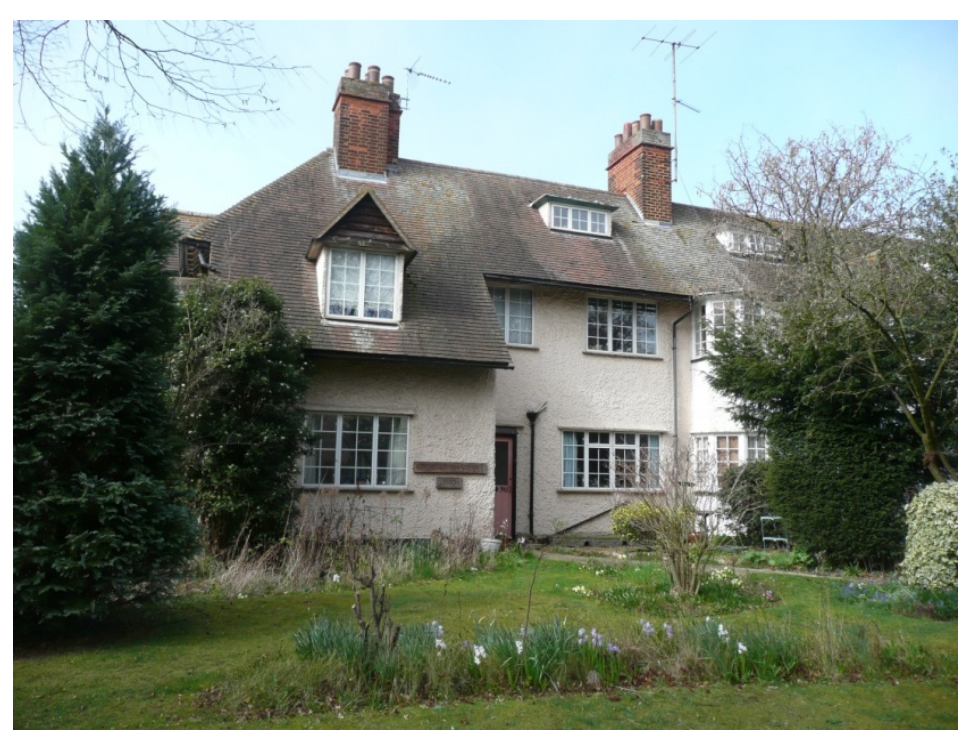

Figure 1. Home of Ebenezer Howard, Letchworth Garden City, 2012 (author's photograph).

transferred the entire estate, then valued at 56 million pounds, to the Letchworth Garden City Heritage Foundation. (Letchworth Garden City Heritage Foundation, n.d.) Today, the foundation "proactively" manages its commercial assets and the income they generate to support its charitable activities and to maintain the properties, on the principle that "value is predominantly created from our property portfolio and therefore the successful management of this portfolio is critical to our success." The ultimate objective is "the maintenance and 
enhancement of the physical, economic and social environment of Letchworth Garden City." With that goal ever in mind, they draw a direct connection between preservation and sustainability: "This objective is driven by our commitment to sustainability. This is about helping to maintain and enhance the town to ensure that its success continues for the long term. This can be achieved through the positive and environmentally sensitive management of the Garden City Estate, combined with investment in our charitable commitments to support the town's social and economic infrastructure" (Letchworth Garden City Heritage Foundation, b, n.d.).

The Foundation's strategic plan for 2011 to 2016 confronts this challenge by emphasizing that their design standards "have been created to help safeguard the town's existing physical character for the benefit of all local communities and future generations - locally, nationally, and internationally." Their goal is "to be a living model of an environmentally sustainable town." Central to that is meeting the needs of the business community, because only a "strong economic environment" will sustain the town's future (Letchworth Garden City Heritage Foundation, c, n.d.). The Foundation understands that only through strict regulation can they maintain economic value, the cornerstone of environmental and social sustainability.

\section{Hampstead Garden Suburb}

In 1907, four years after work began at Letchworth, Dame Henrietta Barnett dug the first spade of earth for England's second planned community, Hampstead Garden Suburb. It was her personal vision that brought the Suburb to life. For years she and her husband tended the parish of St. Jude's Whitechapel in London's working class East End, but they also had a cottage near Hampstead Heath, a bucolic and unspoiled expanse north of the city. After learning of plans for the extension of the underground to Hampstead, Dame Henrietta formed a syndicate to purchase an extensive open tract to guide and control future development. When Eton College, the owner, informed her they would not sell to a woman unless she had the support of men of substance, she quickly lined up an impressive list of backers. Together they formed a syndicate to purchase the open land. What resulted was, in the words of architectural historian Nicholas Pevsner, "the most nearly perfect example of that English invention and speciality, the Garden Suburb" (Miller 1995).

From the very beginning the Suburb was governed by a trust controlling all new construction and alterations to existing structures within its boundaries. Aesthetic considerations were especially singled out among the founding principles. "The houses will not be put in uniform lines nor in close relationship built regardless of each other," the rules stated, "or without consideration for picturesque appearance. Great care will be taken that the houses shall not spoil each other's outlook, while the avoidance of uniformity or of an institutional aspect will be obtained by the variety of the dwellings, always provided that the fundamental principle is complied with that the part should not spoil the whole, nor that individual rights be assumed to carry the power of working communal wrong" (Hampstead Garden Suburb Trust n.d.). The founders understood that the long-term integrity of the Suburb depended upon that fundamental principle, that all residents accept a common set of design standards. 


\section{Proactive Preservation}

This paternalistic system of regulation worked well until the 1967 Leasehold Reform Act, which fundamentally changed the relationship between estate owners and their tenants across the United Kingdom (legislation.gov.uk 2013). The law introduced a serious challenge to the character of the garden suburbs. In Hampstead, the Trust owned all homes prior to 1967, and the old leases contained covenants providing the ground landlord the control necessary to protect his investment. The new legislation removed those provisions, so for the first time, a resident could purchase the freehold of his house. The cohesive character of residential areas previously ensured through oversight by a single landlord could potentially be compromised by the interests of newly enfranchised homeowners wishing to maximize their new asset. But the Act also enabled the ground landlords of "well run" estates to apply to the High Court to set up such a Scheme of Management to control alterations houses and grounds (Hampstead Garden Suburb Trust Scheme of Management, 1983). Accordingly, residents of Hampstead reestablished the Trust and set up a Scheme of Management "for the purpose of ensuring the maintenance and preservation of the character and amenities" of the Suburb (The Trust Gazette 2010).

Letchworth Garden City Corporation initially applied for an exemption to the Leasehold Reform Act, but when that was denied they also submitted a Scheme of Management for the court's approval. The new covenants explicitly required the maintenance of the exteriors of buildings, hedges, and fences to standards set by the Letchworth Garden City Corporation, and owners could not "alter, extend or rebuild without written Corporation consent." This provided "continuity with the previous leasehold covenants." Absent these new controls, it is likely that the character of the garden city could have been preserved. Even so, "visually unsympathetic alterations" using inferior materials proliferate (Miller 1989).

In the mid-1960s, public sentiment was turning away from the urban renewal approach that had characterized England's post-war reconstruction, and many questioned why historic buildings and blocks had to be sacrificed for highways or uninspiring housing. Even the beautiful Georgian city of Bath saw block after block of townhouses demolished to make way for new homes. A small book chronicling this outrage was titled The Sack of Bath (Fergusson 1973). Interestingly, this is precisely when the preservation movement gained traction in New York.

In response, the United Kingdom moved toward more pro-active preservation measures. The idea of the "conservation area" was introduced in 1967, under which "the local authority had a duty to identify, designate, and to administer policies for their preservation and enhancement." Hampstead, Welwyn, and Letchworth each received that designation. Another layer of protection was introduced in 1968 with the Town and Country Planning Act. The owners of listed buildings, places granted protection for their special architectural or historic significance, now had to obtain prior consent if they wished to demolish, alter, or extend their properties (Miller 1989).

To face the challenge of residents newly empowered as freeholders as opposed to leaseholders, the Hampstead Garden Suburb Trust was once again armed with the authority to enforce strict controls (Figure 2). As one resident put it after 500 buildings were listed, "It is odd. You pay more to live here, and you can do less. You can't change your windows, create a driveway or do anything really to alter your house. But people like it here. We must be mad" (Webb 1996). But with homes selling for between $£ 800,000$ and $£ 3$ million, (Suburb News 2012) homeowners understandably want what they want, even if their plans are contrary to Trust regulations. Herein lies the contradiction. Strict regulation keeps the suburb a highly desirable 
place to buy, but at the same time the high value of properties attracts individuals who chafe under controls enforced by an external authority.

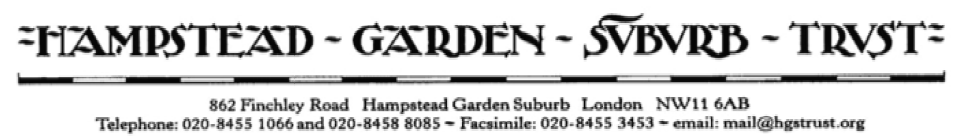

Notice to Freeholders

Please remember that, under the Scheme of Management operated by the Hampstead Garden Suburb Trust, you are required to obtain the prior approval of the Trust before altering the external appearance of your property including the garden.

A non definitive list of alterations which require the consent of the Trust is detailed below:

- Changing windows (including double glazing) and external doors

- Extensions, porches \& other alterations

- Work to patios, driveways \& paved areas in gardens

- Erecting garden sheds

- Re-pointing

- Removing hedges and any work to trees

- Re-roofing

- Chimney alterations

- Replacement of guttering or down pipes

- Erecting satellite dishes

- Installing air conditioning units and extract flues

and

- Converting a garage to another use.

Applications for consent must be made in writing and approved before work commences. Application forms are available from the Trust office or from www.hgstrust.org. To arrange an appointment with the Trust's architectural advisers or tree consultant please telephone the office.

If you are in any doubt about whether Trust consent is required under the terms of the Scheme of Management, or have any other queries, please do not hesitate to contact the Trust Office on 02084551066 during office hours Mon-Fri, 9.00-5.00pm.

Thank you for your co-operation.

February 2011

Figure 2. Notice to Freeholders, Hampstead Garden Suburb Trust, 2011. Even after decades of tight regulation, the Trust residents must obtain prior consensus for all work listed here.

In recent years, the courts and the Lands Tribunal have both affirmed and rejected the Trust's power to regulate. In one case, the Trust had denied an application for a residence above a garage, arguing that it "was out of keeping with the design of the principle part of the house and of others in the area, would reduce views of greenery and would set an undesirable precedent across the Suburb." After the ruling sustaining the Trust's position, Trust Chairman Angus 
Walker said, "As the Lands Tribunal noted, a guiding principle of the Suburb's founders was that the interests of the wider community should prevail over the interest of any individual" (Hampstead Garden Suburb Trust 2010). The Trust was also sustained in demanding that a resident remove 6-foot security gates installed without permission (Brooke 2002). In another case however, the same tribunal allowed the demolition of a well-maintained and handsome house by J.C.S. Soutar, who had been appointed Trust architect in 1915, for construction of two houses. Future battles are to be expected. "The very high value of Suburb property," wrote Trust Manager Jane Blackburn, "means that some owners and developers feel it is worth their while to challenge Trust decisions preventing inappropriate demolition or development through the courts" (Blackburn 2010).

\section{Welwyn Garden City}

Ebenezer Howard began Welwyn Garden City in collaboration with architect Louis de Soissons in the early 1920s, and construction continued into the post-war decades (Our Welwyn Garden City 2013). Like Letchworth and Hampstead, Welwyn, too, thrives under a management scheme imposed "to ensure that homes and street scenes are kept in harmony with the original design and concept of the time." But concern for aesthetics and history alone would not justify strict regulations covering extensions, alterations to or replacement of windows and doors, garden structures, walls and fences, hard surfaces, and trees and hedgerows. The management scheme is important because "inappropriate development, poor quality alterations to buildings and erosion of the special character of the environment will lead in turn to the lowering of neighborhood values both in visual and economic terms." The challenge is to "manage change whilst at the same time ensuring that the fundamental aesthetic, amenities and values of the garden city remain intact." By such means Welwyn could exemplify "sustainable communities" (Welwyn Hatfield Borough Council 2013).

Preservation does not mean freezing a place in time. In 1980, the Welwyn Hatfield Council's Housing Committee voted to demolish 500 homes designed in the 1920s by Louis de Soissons, the original Welwyn architect. The homes were among the earliest examples of loadbearing concrete walls, but after half a century the walls in many houses were unsound. With window frames rusting and heating systems failing, the Council determined that demolition of the still attractive houses and the construction of new structures was the most economical and sustainable solution. The new homes had considerably less charm than the originals, but nonetheless sought to maintain the scale and the general plan. Such a bold decision was certainly at odds with the preservation ethos, but to the managers of the estate, the economic sustainability of the garden city demanded nothing less. Still, an individual commenting on the Our Welwyn Garden City webpage lamented, "Why, when they knocked down these beautiful looking and designed houses, did they rebuild them with soulless and lifeless boxes??" (Hall 2013). Should not sustainability also encompass aesthetic and historical aspects? Or is economic viability the only value?

\section{Garden Suburbs in the Borough of Queens}

The successful application of the garden city idea in London offered a timely precedent to architects and planners in the United States, and the borough of Queens in New York City proved especially fertile ground for such housing experiments. Queens became part of Greater 
New York in 1898. At approximately 120 square miles, it was the largest of the five boroughs in area, but its population was barely 150,000. By 1930, however, Queens was home to 1.1 million inhabitants, an increase of 750 percent. In that context, housing reformers had the room to build innovative planned communities and model tenements, and there was certainly the demand for new housing of any kind. Here the major goals of Howard's garden city ideal could be realized "improved housing at lower cost through the availability of inexpensive land, and increased productivity and happiness of the residents through isolation from the evils of urban environments" (Plunz 1990). The borough's most notable housing experiments were Forest Hills Gardens (1912), Jackson Heights (1911-1929), and Sunnyside Gardens (1924-1928).

\section{Forest Hills Gardens}

Architect Grosvenor Atterbury and landscape architect Frederick Law Olmsted Jr. designed Forest Hills Gardens for the Sage Foundation Homes Corporation adjacent to the new electrified main line of the Long Island Railroad running into Pennsylvania Station. Always intended as an upper middle class suburb, the homes and apartment buildings were designed to the highest standard, with quality materials and a consistent design aesthetic. Mrs. Russell Sage admired the English garden cities and hoped to incorporate their most attractive features in a new community constructed at no greater cost than less attractive housing developments planted on a repetitive grid. According to Frederick Law Olmsted Jr., the goal was to respond to the topography rather than imposing a street grid to obliterate it. "The monotony of endless, straight, windswept thoroughfares which represent the New York conception of streets will give place to short, quiet, self-contained and garden-like neighborhoods," he wrote. In fact, Forest Hills Gardens was the first violation of the street grid in Queens, and perhaps the entire city (Plunz 1990).

In many ways, Forest Hills Gardens consciously followed the goals and standards of Letchworth and Hampstead. Robert A.M. Stern calls it "the most English of American planned suburbs" (Stern 1981). As at Hampstead Garden Suburb, an independent organization has the legal authority to regulate all aspects of the place. The Forest Hills Gardens Corporation is a membership organization of property owners, answerable only to its members. It regulates the buildings and actually owns the streets (a situation unique in New York City). The corporation controls all new construction and alterations "to preserve the original aesthetics and design of our community" (http://foresthillsgardens.org/ 2013). A realtor with an office in Station Square noted, "People understand that their property value has remained strong because of the ironclad covenants and restrictions" (Forest Hills Gardens Corporation 2013). As in the English examples, aesthetic regulation is deemed a key to sustainability.

Forest Hills Gardens is unique in the City of New York in that the community sets and enforces its own standards. The only option available to other places is designation as a historic district under New York City's 1965 landmarks law, a most effective tool for the protection of significant characteristics of historic neighborhoods and buildings. As of 2013, there were 110 historic districts in the five boroughs (Landmarks Preservation Commission 2013). After designation, property owners must obtain permits from the commission for any changes to the facades and hardscape immediately adjacent, including doors and windows, fences, skylights, and paint trim. On the whole, this has worked remarkably well, maintaining the historic features of designated properties while gradually remediating the inappropriate changes that had accrued over the decades. Absent designation, it is unlikely that the character the city's historic neighborhoods, including the garden suburbs, could have been sustained. 


\section{Kew Gardens: Unprotected}

Immediately adjacent to Forest Hills Gardens is Kew Gardens, a similar suburban development of single-family homes and apartment buildings developed at the same time as Forest Hills Gardens. In the 1920s attracted a colony of Broadway entertainers and film stars, including Charlie Chaplin, Will Rogers, and George Gershwin; by 1940 it was all but built out (Lewis 1999). Unlike Forest Hills Gardens, however, Kew Gardens never had a governing authority to enforce aesthetic regulations. For generations, the quality of the architecture, combined with a common value system among the residents, seemed sufficient to maintain the character of Kew Gardens. In recent years, however, new residents embracing a different aesthetic and different wants and needs have significantly altered or even replaced the original homes. For that reason, the Kew Gardens Improvement Association sought protection under the New York City landmarks law. According to association president Sylvia Hack, "For over eighty years, the people of Kew Gardens have valued what they had and have. Now it is all too apparent that unless we achieve historic designation and recognition, the next generation may inherit only a shell of what exists." Unfortunately, their campaign gained no traction at the Landmarks Preservation Commission (LPC), and Kew Gardens remains vulnerable to market forces and the vagaries of individual taste. From the perspective of the long-time residents seeking protection, the city has "sacrificed neighborhoods by short-term thinking when the longer view would have been wiser" (Lewis 1999). It is the embrace of the longer view that distinguishes the management of Forest Hills Gardens and the English garden suburbs from the marketplace of individual needs and tastes in Kew Gardens and other unprotected suburbs.

This suggests another aspect of a regime of strict regulation. While design standards inhibit what one can do with one's property, the same controls also limit what one's neighbors can do. The certainty that comes with landmark designation or a private scheme of management protects the homeowner's investment and increases the value of the property as a home. Conversely, the absence of such controls can inhibit sales, particularly in highly desirable areas attracting interest from developers or investors. Donald Brennan, a realtor active in Brooklyn, contends that there is an enormous downside to owning property outside a historic district. In his calculation, "the cost of having to use a certain type of window is worthwhile insurance to make sure that my neighbor doesn't let his property devolve, or turn around and sell his building to somebody else and it disappears, and then I have a problem as to what will go on next to me." During periods of intense development pressures, there are tremendous risks. "The pro-landmarking argument that values will only rise," says Brennan, "is not as compelling as the argument that values will likely diminish in the absence of designation" (Historic Districts Council 2014).

\section{Jackson Heights}

The second garden suburb in Queens was Jackson Heights, an attractive area of distinctive prewar apartment blocks and single family homes located adjacent to a new subway line. According to Robert A.M. Stern, it is a "model urban suburbia," demonstrating "what high-density housing in the city could be" (Karatzas 1990). The innovative feature of the new garden apartments was the landscaping. Each building is set back from the street to provide a small garden in front, and the landscaped courtyard in the center of each block provides an unprecedented expanse of green from every apartment. In terms of scale and architectural quality, there was nothing like it 
anywhere in the city. Architect Andrew J. Thomas made Jackson Heights a highly desirable neighborhood, and "established humane and practical standards for housing in the city" (Stern 1987). In 1925, delegates to the International Town, City, and Regional Planning Conference, Raymond Unwin and Ebenezer Howard among them, visited Jackson Heights to see their garden city idea modified for an apartment building neighborhood (Plunz 1990).

Edward A. MacDougall's Queensboro Corporation (named for the recently completed Queensboro Bridge) erected the first apartment building in Jackson Heights in 1911, and the development was largely complete by the onset of the Great Depression. From the beginning, the Queensboro Corporation imposed design standards on land they sold to developers, assuring a harmonious ensemble of high quality buildings. After World War II, such restrictions were abandoned, and all remaining open land sprouted buildings of lesser architectural character. Originally, the apartments were co-ops, among the first in the city. During the Great Depression, however, many co-op owners fell into foreclosure and the units became rentals; they remained rentals until the first wave of co-op conversions in the 1970s and 1980s (Karatzas 1990).

A renewed building boom in the 1980s targeted underbuilt sites, primarily free-standing single family homes and low-rise commercial blocks, and "a number of buildings were bulldozed or 'improved' to the point where there were unrecognizable." What saved Jackson Heights from the fate of other Queens neighborhoods was its density and the quality of the housing - brick as opposed to wood-frame and attached and semi-attached houses as opposed to free-standing dwellings. Though there was little danger that the larger garden apartment blocks would be demolished, it was quite possible that the architectural elements could be stripped from the facades in the name of safety or economic necessity. In 1980, after a pedestrian was struck and killed by a piece of a cornice falling from a Manhattan building, the City Council enacted Local Law 10, which mandated the inspection of "exterior walls and appurtenances" (Local Laws for the City of New York 1980). Not surprisingly, many building owners wasted no time in stripping all architectural ornament from facades.

Fearing that incremental changes would undermine the harmony of the architecture and ultimately threaten property values, residents formed the Jackson Heights Beautification Group in 1988 to maintain the character of the historic blocks and push for protection under the landmarks law (Jackson Heights Beautification Group 2013). Only five years later Jackson Heights was designated a historic district encompassing 38 blocks of garden apartments and oneand two-family houses (Landmarks Preservation Commission 1993). The LPC now regulates all buildings and open spaces in the district, and residents continue to lobby for an expansion of the protected zone.

\section{Sunnyside Gardens}

The third historic garden suburb in Queens is Sunnyside Gardens, built by the City Housing Corporation between 1924 and 1928. The housing reformers behind the project - Lewis Mumford, Alexander M. Bing, and the architects of Sunnyside, Clarence Stein, Henry Wright, and Frederick L. Ackerman - consciously took the English garden cities for their model. Though the houses were small, the innovative planning and generous landscaping made for an attractive and affordable suburban enclave near a new elevated line running into Manhattan. A key feature was a common courtyard in the interior of each block, or in the mews configurations, a shared front garden (Stein 1978). Mumford actually lived there for a time. In Green Memories, his poignant tribute to his son Geddes, killed in combat in 1944, he wrote, "what the houses 
themselves lacked in imaginative design, the community as a whole made up for in open spaces, carefully reserved for public use, in playgrounds and gardens on a scale then unheard of anywhere else in the city, and in opportunities for spontaneous neighborliness. Something more than our isolation, something more than the fact that the rear gardens and lawns were not choked with asphalt pavements and garages, gave us the sense of a common purpose. Even those who were only grasping at a 'good buy' found themselves enjoying a good life" (Mumford 1947).

Sunnyside Gardens was tightly regulated for almost its entire history. For the first forty years, the original covenants protected the courtyards and maintained strict control over ordinary maintenance and alterations. When those covenants expired in the mid-1960s however, some homeowners responded like it was the Oklahoma Land Rush, erecting fences to claim property that had formerly comprised "the common" and paving over front gardens for parking pads. "Bitter arguments broke out between neighbors, pitting preservationists, many of them older residents, against those seeking privacy or merely asserting their new property rights," wrote one resident. "Spite fences were erected, followed by retaliatory hedges to cover the fences. Friends stopped speaking to one another, and some families even moved away" (Havelick and Kwartler 1982). In truth it was their property they were reclaiming, and they did pay taxes on their full lot, even if part of their lot was included in the common defined by the lapsed covenants.

After almost a decade of such incursions - and it is remarkable that so few homeowners took advantage of the absence of regulation during that interlude - the city created a new zoning category to protect Sunnyside Gardens - the Special Planned Community Preservation District (that designation also covered Fresh Meadows in Queens, Parkchester in the Bronx, and the Harlem River Houses in Manhattan). The special zoning protected the open space, limited the ability of homeowners to build additions or enclose porches, prohibited the removal of mature

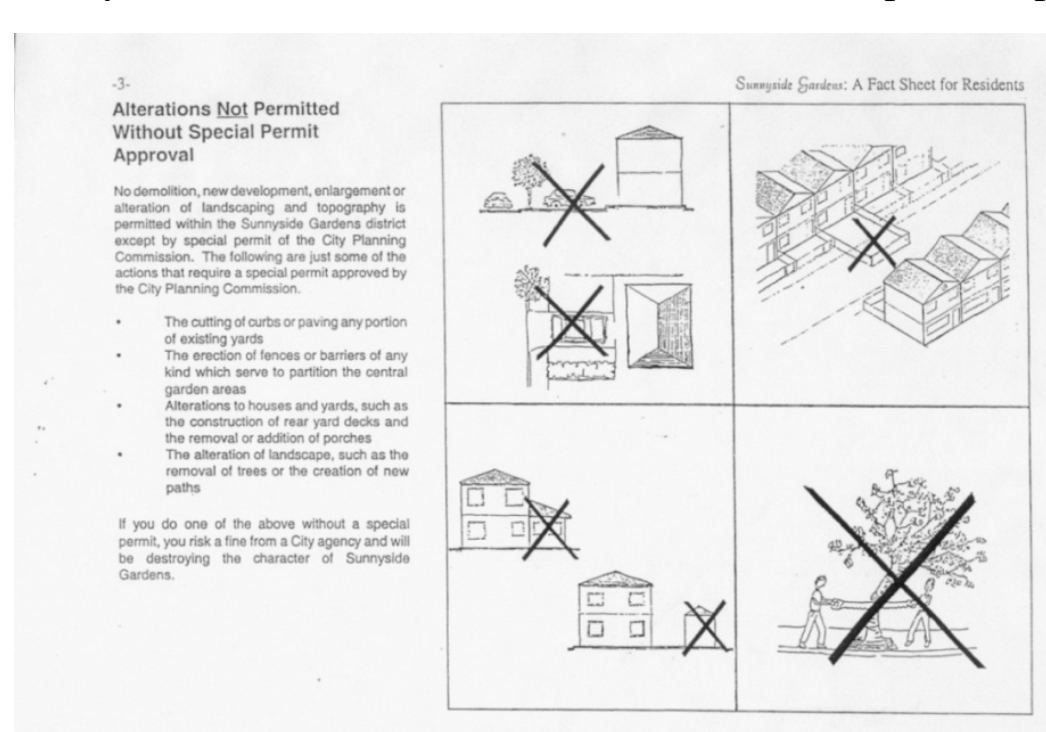

Figure 3. Sunnyside Gardens: A Fact Sheet for Residents, Department of City Planning, ca. 1980. To the dismay of preservationists, the City Planning Commission removed these protections from Sunnyside Gardens when the zoning was changed after designation as a historic district, leaving the Landmarks Preservation Commission the sole arbiter of what is permissible in the district. trees, and banned new driveways and curbcuts. The Department of City Planning prepared a brochure with clear illustrations showing exactly what was prohibited under the special zoning without a special permit (Figure 3) (Department of City Planning n.d.).

What the special district designation did not protect was the architecture, leaving the homes still vulnerable to the gradual erosion of features like windows, doors, fencing, slate roofing, and wood trim. For that reason, residents formed the Sunnyside Gardens Preservation Alliance to press for designation as a historic district. During the 


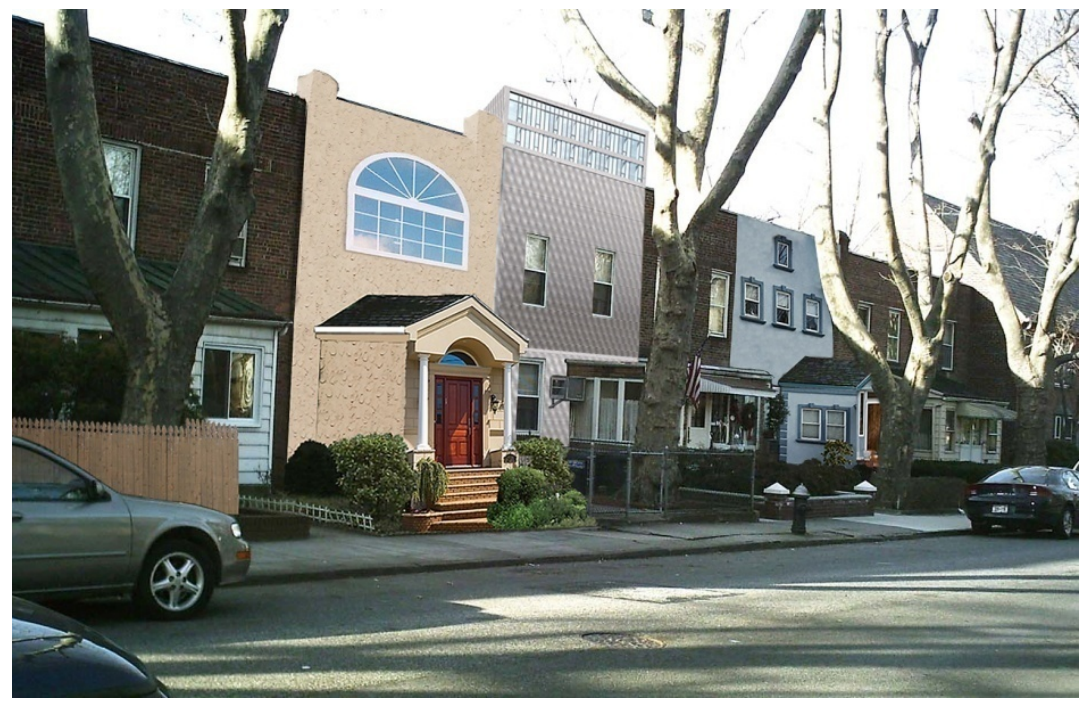

Figure 4. During the effort to gain historic district designation, landmarking proponents prepared this photo-shoped image to show what could happen to the brick rowhouses in Sunnyside Gardens subject to individual taste absent the protection of New York City's Landmarks Preservation Commission (Laura Heim Architect, 2007). surprisingly contentious campaign to secure designation, opponents contended that the special zoning was sufficient protection for the open space and argued that the architectural details were insignificant. Supporters countered with photoshopped images showing what kinds of alterations were possible under the zoning but would likely be prohibited after landmarking (Figure 4). After several years of public meetings and hearings, the Landmarks Commission finally voted to designate Sunnyside Gardens

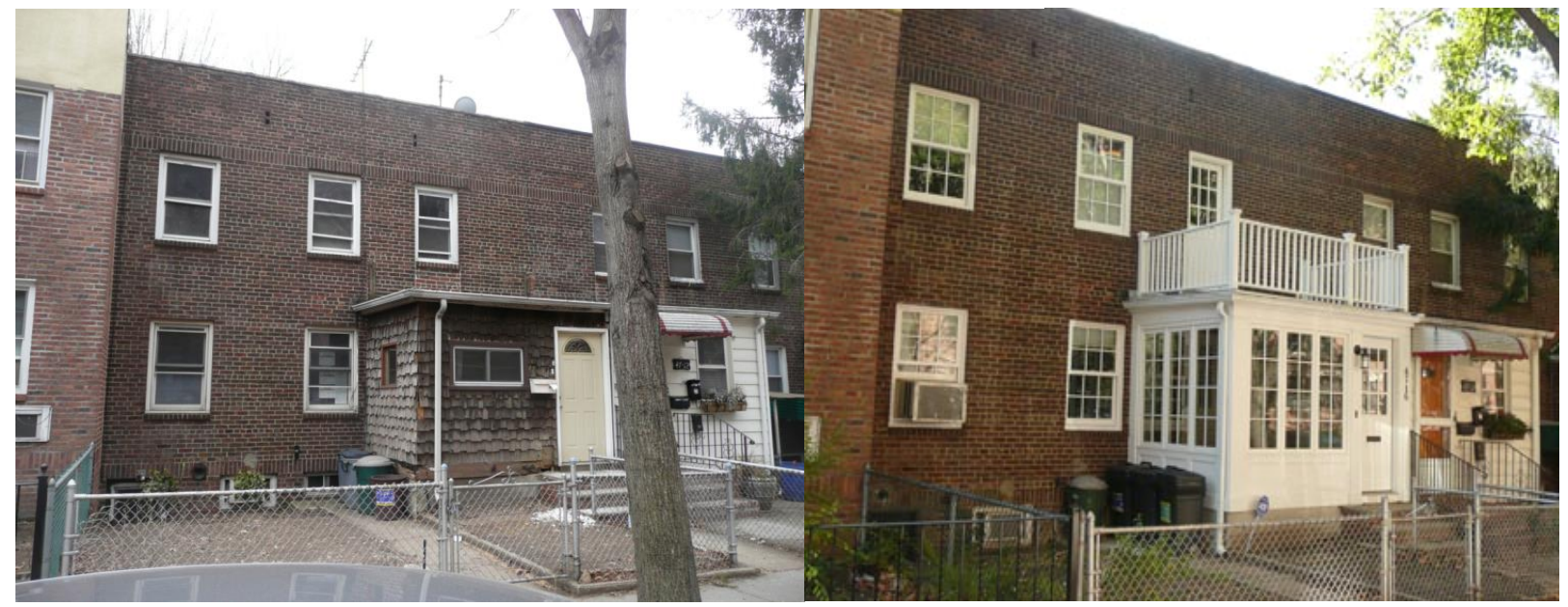

Figure 5. A rowhouse in the Sunnyside Gardens Historic District before designation and after restoration with Landmarks Preservation Commission approval. Many houses are regaining architectural details lost prior to designation (Laura Heim Architect, 2009).

and the adjacent Phipps Garden Apartments in 2007 (Landmarks Preservation Commission 2007).

Since designation, many homeowners have restored the historic features that had been lost or compromised over the decades, and as a result property values in the district have risen faster than on surrounding blocks (one 952-square foot home sold for $\$ 810,000$ in 2013; a similar house sold for $\$ 460,000$ the year prior to designation) (realtor.com 2013). But as at Hampstead, eternal vigilance is the price of protection. Still, some homeowners willfully defy the rules, and preservationists must trust that the Landmarks Commission will enforce strict design standards (Figure 5). Not infrequently, the LPC disappoints preservation-minded residents by approving work using inferior materials or denies the precedent of decades of regulation. Further 
complicating matters, rather than import the rules in place under the old special zoning, as many residents favoring designation had expected, the Commission chose to apply rules based on precedents in other historic districts entirely different in character. In some instances, applicants have been permitted changes that would have been prohibited under the old zoning, as the Commission considers each application on a case-by-case basis.

\section{Conclusion}

Any suburb is sustainable as a community only so long as it remains economically viable and a desirable place to live. In the case of these landmarks of planning in London and New York, aesthetic regulation has been a major factor in maintaining property values, and it is indeed likely that without such controls these places would have been lost, absorbed by the sprawling city. Strict guidelines also contribute to a distinctive sense of place and thus enhance its attractiveness to potential residents by assuring that their investment will be protected.

At the same time, the early twentieth century garden cities are worthy of preservation in their own right. These six places in particular represent an optimistic moment in the history of urban housing and design, and having only plans and photographs would scarcely substitute for wandering the streets. It is not enough that we know Ebenezer Howard lived in the garden city he built; we have to be able to see his house.

Urban historians and planners continue to study and admire these historic garden cities, but these places are still home to individuals with diverse taste, needs, and wants. If the goal of long-term sustainability is to be realized, the suburbs have to adapt to contemporary living, but not at the cost of lower standards of regulation. Only through strict and consistent regulation can homeowners be assured that property values will remain solid, because that is the best guarantee that the community will endure. Indeed, only tight controls will insure that Letchworth, Hampstead, and Welwyn, Forest Hills Gardens, Jackson Heights, and Sunnyside Gardens remain intact to celebrate their bi-centennials.

\section{References}

Allison, E. and Peters, L. 2011. Historic Preservation and the Livable City. Hoboken, New Jersey: John Wiley \& Sons.

Blackburn, J. "Trust wins landmark case." Suburb News 104.

Brooke, C. June 19, 2002. "Your gates must go; Lawyer ordered to remove barriers put up to protect his family after four robberies at his luxury home." Daily Mail (London).

Buder, S. 1990. Visionaries and Planners: the garden city movement and the modern community. New York: Oxford University Press.

Department of City Planning, City of New York. "Sunnyside Gardens: A Fact Sheet for Residents." n.d.

Fergusson, A. 1973. The Sack of Bath. London: Persephone Books.

Fishman, R. 2002. "The Bounded City." In From Garden City to Green City: the legacy of Ebenezer Howard, eds. K. C. Parsons, Schuyler, D., 58-66. Baltimore: The Johns Hopkins Press.

Forest Hills Gardens Corporation. Accessed 2013. http://foresthillsgardens.org/. 
Hall, S. 2013. "20 million plan to rebuild homes.” Accessed 2013. http://www.ourwelwyngardencity.org.uk/page_id_538_path_0p162p.aspx.

Hampstead Garden Suburb Residents Association. Brochure. n.d.

Hampstead Garden Suburb Scheme of Management, Approved pursuant to the Leasehold Reform Act 1967, by an Order of the Chancery Division of the High Court, dated $17^{\text {th }}$ January 1974, as amended by a further Order dated $17^{\text {th }}$ February 1983.

Hampstead Garden Suburb Trust. An Introduction to the role, procedures and operations of the Trust. n.d.

Hampstead Garden Suburb Trust. n.d. Hampstead Garden Suburb Conservation Area: Design Guidance.

Hampstead Garden Suburb Trust. 2010. Report and Accounts for the Year 5 April 2010.

Hampstead Garden Suburb Trust. September 2010. Hampstead Garden Suburb Scheme of Management. 8.

Havelick, F. and Kwartler, M. 1982. "Sunnyside Gardens: Whose Land Is It Anyway?" New York Affairs 7(2): 65-80.

Historic Districts Council. 2014. District Lines.

Howard, E. 1965. Garden Cities of To-Morrow. Cambridge, Massachusetts: MIT Press.

Jackson Heights Beautification Group. http://www.jhbg.org/resources/history, accessed 2013.

Leasehold Reform Act. 1967. Accessed 2013. http://www.legislation.gov.uk/ukpga/1967/88/enacted.

Letchworth Garden City Heritage Foundation. "A Brief History.” Accessed 2013.

http://www.letchworth.com/heritage-foundation/letchworth-garden-city/a-brief-history.

Letchworth Garden City Heritage Foundation. "Our Objectives.” Accessed 2013. http://www.letchworth.com/heritage-foundation/about-us/our-objectives.

Letchworth Garden City Heritage Foundation. 2011. "Strategic Plan, October 2011 to September 2016." www.letchworth.com, accessed 2013.

Lewis, B. 1999. Kew Gardens: Urban Village in the Big City. Kew Gardens: Kew Gardens Council for Recreation and the Arts.

Miller, M. 1995. Hampstead Garden Suburb. Chalford, England: The Chalford Publishing Company.

Miller, M. 1989. Letchworth: the First Garden City. Chichester, England: Phillimore \& Co. Ltd. Mumford, L. 1965. The Garden City Idea and Modern Planning. In Howard, E. Garden Cities of To-Morrow. Cambridge: MIT Press.

Mumford, L. 1947. Green Memories: the story of Geddes Mumford. New York: Harcourt Brace.

New York City Landmarks Preservation Commission. Accessed 2013. http://www.nyc.gov/html/lpc/html/home/home.shtml.

New York City Landmarks Preservation Commission. 1993. Jackson Heights Historic District. Accessed 2013.

(http://www.nyc.gov/html/lpc/downloads/pdf/reports/JACKSON_HEIGHTS_HISTORIC_ DISTRICT.pdf).

New York City Landmarks Preservation Commission. 2007. Sunnyside Gardens Historic District Designation Report. Accessed 2013. (http://www.nyc.gov/html/lpc/downloads/pdf/reports/SunnysideGardens.pdf).

New York City, Local Law No. 10. 1980. Accessed 2013. (http://www.nyc.gov/html/dob/downloads/pdf/ll_1080.pdf).

Our Welwyn Garden City. Accessed 2013. http://www.ourwelwyngardencity.org.uk/. 
Plunz, R. 1990. A History of Housing in New York City: dwelling type and social change in the American metropolis. New York: Columbia University Press.

Realtor.com. Accessed 2013.

Stein, C. S. 1978. Toward New Towns for America. Cambridge, Massachusetts: The M.I.T. Press.

Stern, R. A. M. 1981. The Anglo-American Suburb. London: Architectural Design.

Stern, R. A. M. Gilmartin, G. Mellins, T. 1987. New York 1930: architecture and urbanism between the two world wars. New York: Rizzoli.

Suburb News

The Trust Gazette

Webb , G. November 29, 1996. "Why they listed this Eden that is Hampstead's garden." Evening Standard (London).

Welwyn Hatfield Borough Council. 2013. "Welwyn Garden City Estate Management Scheme." Accessed 2013. www.welhat.gov.uk.

Young, R. F. 2002. "Garden Cities and the Urban Future." In From Garden City to Green City: the legacy of Ebenezer Howard, eds. K. C. Parsons, Schuyler, D., 201-221. Baltimore: The Johns Hopkins Press. 